\title{
New Experiences in Pedagogical Lexicography: Two Cuban School Dictionaries
}

\begin{abstract}
The Santiago-based Centro de Lingüistica Aplicada has produced two school dictionaries, the Diccionario Escolar Ilustrado and the Diccionario Básico Escolar, which together cover the 12 grades from Primary School over Secondary Basic School to High School. In various ways they are innovative in terms of the solid preparatory work, the design and content of the articles, the cheap production methods, and the work that has been carried out with a view to effectively reaching the target user group with an output of until now more than 100000 printed copies as well as their accessibility on $\mathrm{CD}$, the Internet and the Cuban national Intranet (soon). The article analyses the two dictionaries in terms of their methodology, functions, content, structure, and layout and presents some suggestions for future editions as well as for pedagogical lexicography in general.
\end{abstract}

\section{Introduction}

Dictionary culture, as defined by Hausmann (1989: 13), starts in school. The extremely useful and advantageous habit of consulting dictionaries (and other lexicographical works) when one has lexicographically relevant information needs, together with the necessary skills to accomplish a successful consultation process, is above all developed in school. A precondition for the development of such a habit is the existence of properly designed school dictionaries, especially the ones conceived to assist the learning of the mother tongue (or first language). High-quality dictionaries and successful consultation is a sine qua non for a proper dictionary culture and enthusiasm. In this respect, a school dictionary should not be understood as any dictionary used in school or any dictionary disguised as such, e.g. "school" dictionaries that are simple reductions of more comprehensive general dictionaries. Only dictionaries that have been conceived and compiled from scratch and adapted to the specific characteristics and needs of school children should be considered school dictionaries in the true sense of the word, cf. Hernández (1989: 52), Welker (2008: 302), Gouws and Tarp (2010: 468), Tarp (2011a: 225).

It goes without saying that while dictionary culture may be a general and long-term objective of school dictionaries, it can never constitute their immediate purpose. School dictionaries, as well as all other dictionaries, are always consulted by specific types of users with specific types of needs occurring in specific types of situations and their immediate function is therefore to satisfy these needs, whether they are of a communicative, cognitive or operative type. However, in comparison to other users of lexicographical products, school children constitute a highly heterogeneous user group which has to be graduated according to age (grade) and the corresponding intellectual, linguistic, cultural, and encyclopedic development, cf. Gouws and Tarp (2012). The big challenge is the design of school dictionaries that are adapted to this heterogeneous user group in terms of its characteristics in continuous development as well as the various learning situations or activities where lexicographically relevant needs may occur. And the big question raised is how many grades one school dictionary may actually cover when it has to include both all the data and

\footnotetext{
* Sven Tarp

Centre for Lexicography

Department of Business Communication

Aarhus University

Fuglesangs Alle 4

DK-8210 Aarhus $V$

st@asb.dk
} 
data categories needed to satisfy the upper-level users and avoid that these data "disturb data access and information retrieval for learners at a lower level because the latter may find it difficult navigating in articles with too many and too complex data categories included" (Gouws and Tarp 2012).

\section{Two Cuban school dictionaries}

The Centro de Lingüistica Aplicada (Centre for Applied Linguistics) is a scientific research body situated in Santiago de Cuba, founded in 1971 by Eloína Miyares Bermúdez and Vitelio Ruiz Hernández and today lead by their son Leonel Ruiz Miyares, cf. Avendaño (2011). Among other publications from this centre are two school dictionaries, the Diccionario Escolar Ilustrado (Illustrated School Dictionary) and the Diccionario Básico Escolar (Basic School Dictionary), both of them edited by Eloína Miyares Bermúdez who has an academic background first as a teacher and later as a researcher of linguistics and first-language learning. The first dictionary was published in 1998, the second in three editions (2003, 2008 and 2009) with a reprint in 2011, and both are expected to appear in a new edition at the end of 2012. Apart from the printed version, the Diccionario Básico Escolar has been published on CD as well as on the Internet from a Basque server, cf. Alegría et al. (2006), and is expected to be accessible on the Cuban national Intranet in 2012. And according to Heredia et al. (2011), an electronic version of the Diccionario Escolar Ilustrado also seems to be on the stocks in 2012. Although these two dictionaries were first published several years ago and have been reviewed various (but surprisingly few) times - e.g. Corpas (2005), Forgas and Bargalló (2006), Nomdedeu (2012) - their distinctive characteristics and the fact that they will appear in new editions in the near future nevertheless justify the following comments (and recommendations).

The two lexicographical works mentioned are school dictionaries in the true sense of the word as they have both been completely designed and compiled from scratch, and they are in various ways exceptional in the Spanish-speaking world not only due to their specific content and design but also to the research process that preceded them and the special type of promotion that followed their publication.

The preparatory work took place between 1990 and 1995 when a study of the active-functional vocabulary of Cuban primary-school children between $2^{\text {nd }}$ and $6^{\text {th }}$ grade was accomplished based upon a total of 7001 (5 873 written and 1128 oral) compositions collected in both rural and urban areas in nine of Cuba's then fourteen provinces. This study, which was later published in Miyares et al. (2006), not only allowed the researchers to establish the urban and rural school children's growing - and varying - active vocabulary over five grades ( 8 to 12 year) but also their specific problems in terms of oral and written text production, especially orthography. The result was a corpus of 700000 codified words which constituted the central (but not only, as we shall see) part of the corpus which eventually assisted the compilation of the two dictionaries. Contrary to the claim of Hernández (2003: 24) according to whom "there is not a single [Spanish] school dictionary which clearly informs about the sources of its nomenclature", the Santiago-based Centro de Lingüistica Aplicada has from the very beginning been very informative about its sources and methodology which have been explained in great detail in various publications, e.g. in Miyares and Ruiz (2006). However, what distinguishes the lexicographical basis of the two Cuban school dictionaries is not so much the existence of a corpus. Corpora composed of textbooks, exercises, etc., are generally used in the compilation of school dictionaries, see, e.g., Michael Rundell's (2004) Introduction to the Macmillan School Dictionary. The really interesting thing is the fact that the corpus in this case includes texts composed by the target user group itself, allowing the lexicographers to get a much more profound knowledge of the real needs of this group which Wiegand (1977: 59) once called the "well-known unknown".

In addition to the preparatory work, the Centro de Lingüistica Aplicada has also developed a special approach to the finished product in terms of printing and promotion. In Third World countries, the relatively high prices of dictionaries prevent many poor families from purchasing them 
for their children, and as they do not have a market for this product, many publishing houses are reluctant to invest in the necessary research and development of new and more didactic dictionaries, cf. Gouws and Tarp (2012). In South Africa no solution has yet been found to this problem. In Brazil, during the last decade, the government provided each school child with a dictionary, an initiative that has greatly encouraged dictionary culture and the whole lexicographical milieu. In Cuba, the Ministry of Education has opted to subsidize the third edition of the Diccionario Básico Escolar (a total of 100000 copies). The use of relatively cheap paper has made it possible to offer this 1200-pages, two-volume dictionary at the ridiculously low price of 30 Cuban Pesos (about one Euro) thus making it accessible to any Cuban family with school children. Finally, in order to promote their lexicographical products, the Centro de Lingüistica Aplicada has organized what they call "caravans" to visit the various municipalities on the island to promote the dictionary, and it has sponsored meetings in 36 of Cuba's 168 municipalities where the authors themselves have introduced - and donated - the dictionary to teachers and other people interested in the dictionary. This has allowed the establishing of direct links to the schools and, ultimately, to close the circle that started with the research into the school children's active-functional vocabulary. These efforts have led to a steady and growing interest and demand for the Diccionario Básico Escolar, which will eventually lead to a fourth edition to be printed in 2012 with an output of some 50000 copies (information provided by the Director of the Centre Leonel Ruiz Miyares).

\section{Diccionario Escolar Ilustrado}

According to the authors, the Diccionario Escolar Ilustrado is designed to attend the lexicographical needs of the pupils in the first four Grades of Primary School, i.e. children from about six to ten years old. Its 2000 lemmata, mainly nouns, have been selected from the corpus described above, to which have been added words taken from various text books. The articles consist of very few data categories: the lemma, the warning (in read letters) against common spelling mistakes, an explanation where the lemma is repeated and highlighted in bold, and, in 25 per cent of the cases, a coloured illustration to support the explanation. Only a few articles include more than one sense of the lemma, and in these cases the various senses are indicated by numbers. The graphical presentation is very aesthetic and tempting with big letters, a lot of colours and an average of ten articles on each page. As such, the dictionary displays many of the characteristics which Hausmann (1990: 1365) lists as being typical for what he calls "children's dictionaries" but which in most cases may be considered school dictionaries because they are actually conceived for school children, cf. Tarp (2011a: 227).

As it is common in many dictionaries, the authors are not very precise when it comes to defining the functions of their product. In her Preliminary Words, Eloína Miyares Bermúdez points to the children's "needs for understanding the meaning of the words and, in general, a better knowledge of the Spanish language". Miyares and Ruiz (2006) provide further details:

- "one of its objectives is that the school children become familiar with the use of this important linguistic tool” (p. 101);

- "the children will learn other words which contribute to their cognitive formation and, in the end, a better interpretation of the reality that surrounds them" (p. 102); and

- "the dictionary tends to achieve a good orthography" (p. 103).

"Language knowledge" (conocimiento de la lengua) is a dual concept as it can both refer to language skills and learned knowledge of the language. This distinction is very important from a lexicographical point of view because dictionaries, on the one hand, may transmit learned knowledge, e.g. knowledge of the origin and grammar of a specific language, directly to their users while they, on the other hand, can only indirectly assist the development of language skills which necessarily have to be mediated by communication, cf. Tarp (2008: 131-136). Taking into account the age and needs of the target user group, it seems that language knowledge in this case refers 
exclusively to language skills mediated by "understanding" and "orthography", i.e. text reception and production. Apart from these two communicative functions, the dictionary, according to Miyares and Ruiz (2006: 102), also has an important cognitive function, i.e. contributing to the children's "cognitive formation" and "a better interpretation of the reality that surrounds them". As to the familiarization with the use of dictionaries, this declared objective can only be achieved in the long run if the dictionary successfully assists the school children when they have more direct and immediate needs in terms of the other functions mentioned, i.e. text reception, text production and cognitive formation. It is in this light that the dictionary should be evaluated.

As to assistance with text production, the dictionary contains orthography, warning against spelling mistakes, and implicit indication of how to use the words in various contexts provided by the explanation. No explicit grammatical data of any sort is provided. The mentioned data categories seem to be all that the target user group is able to assimilate, and in this respect the dictionary fulfills its function.

As to assistance with text reception, the explanations - sometimes backed up by illustrations - consist of one or more sentences which are descriptive, written in a simple and clear language and as a rule related to the children's universe. In some cases the authors have also opted for definitions in the narrow sense of the word, but the underlying idea seems to be that the children will intuitively retrieve the meaning from the context, and in this respect the dictionary also fulfills its function. Here are a few examples: edad: El sábado Sandra cumple ocho años de edad y le harán una fiesta.
(age: Next Saturday, Sandra becomes eight years of age and will have a party.)

escarbar:Alos pollitos de tíaAlicia les gusta mucho escarbar. Escarbar es removervarias veces la tierra. (scratch: Aunt Alicia's small chickens like very much to scratch. To scratch is to move the soil several times.)

marinero: José quiere ser marinero para trabajar en un barco y viajar por el mar. Los marineros pasan mucho tiempo en el mar; buscan mercancías y las llevan de un lugar a otro. (seaman: José want to be a seaman in order to work on a ship and travel on the sea. The seamen spend a long time on the sea; they pick up goods and take them from one place to another.)

As to the cognitive function, the authors inform that they "took into account psychological, educational, ethical, scientific, and patriotic criteria" when they wrote the explanations, cf. Miyares and Ruiz (2006: 102). The following examples give an idea of how these criteria have been implemented and how the dictionary also fulfills its declared cognitive function as formulated by its authors:

ley: Carlos cumple con las leyes del tránsito. Una ley es una regla que dice cómo debemos actuar.

(law: Carlos obeys the traffic laws. A law is a rule that tells us how to behave.)

mambí: Los mambises eran muy valientes. Ellos pelearon por ver libre a Cuba. Guillermo Moncada fue un bravo mambí.

(mambi: The mambises were very brave. They fought to see a free Cuba. Guillermo Moncada was a brave mambi.)

maní: Mi mamá me trajo un cucurucho lleno de maní tostado y me lo comí todo. El maní es una semilla que tiene grasa y se utiliza para hacer aceite. Sirve, además, para hacer turrones y otros dulces. (peanut: My mother brought me a paper cone full of toasted peanuts and I ate all of it. The peanut is a seed that contains fat and is used to make oil. It is also used to make nougat and other kinds of sweets.)

mes: El mes próximo comenzarán las vacaciones. Un mes es cada una de las doce partes en las que se divide un año. Los meses del año son enero, febrero, marzo, abril, mayo, junio, julio, agosto, septiembre, octubre, noviembre y diciembre.

(month: The holidays begin next month. A month is each of the twelve parts into which the year is 
divided. The months of the year are January, February, March, April, May, June, July, August, September, October, November and December.)

To sum up, the Diccionario Escolar Ilustrado seems to be very well-adapted to the target user group's intellectual, linguistic, cultural, and encyclopaedic level. It is, in various ways, an innovating and excellent dictionary for school children of the first four grades. The only recommendation of importance in regard to a new edition would be to use a search-field structure, cf. Wiegand (2000), in the relatively few cases where more than one sense is addressed to the lemmata. Various research projects have indicated that many users give up before they reach the second and even more the third or fourth sense in the same article, and this will surely also apply to lexicographically inexperienced school children at the age of six to ten. Consequently, it could be recommended that the dictionary instead of using a compact article structure:

canal: 1. Me gusta tirarme por el canal del parque. 2. En la agricultura se usan canales para regar la tierra. 3. En la televisión hay varios canales. Yo prefiero el canal donde pasan los muñequitos.

should use the following search-field structure whose only inconvenience is that it is more spaceconsuming:

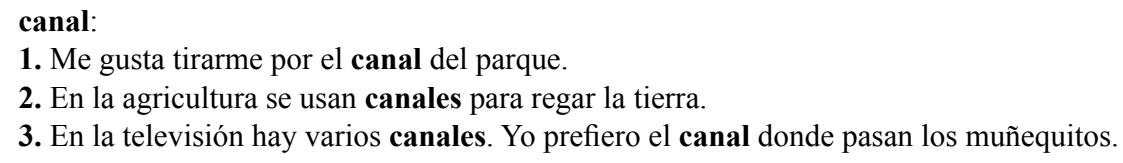

\section{Diccionario Básico Escolar}

The Diccionario Básico Escolar, according to Miyares and Ruiz (2006: 104), is conceived to meet the lexicographical needs of school children attending the "second circle" of Primary School (Grades 5 to 6), the Basic Secondary School (Grades 7 to 9) and High School (Grades 10 to 12), i.e. a total of eight grades with children from about ten to eighteen years old. To this should be added, according to the Introduction to third edition, the students of "polytechnic centres and the user of the Computer Youth Clubs", i.e. users within the same age group. By contrast, no unambiguous information is provided about the learning situations and activities in which it can be used by the defined target user group. In the already mentioned Introduction to the third edition, the editor and main author Eloíne Miyares Bermúdez writes:

"This third edition comprises more than 10500 entries and about 20000 senses, all of them basic and fundamental for the knowledge and normative use of the language. The majority of the entries express different spheres of reality, especially aspects of social life, nature, science, culture, sport, and other novel elements that allow the actualization of the knowledge of the young and also the adult people."

Miyares and Ruiz (2006) provide further details:

\footnotetext{
"Its main objective is that the school children achieve an enlargement and better knowledge of the Spanish vocabulary as well as an improved orthography and proper use of the words according to their function." (p. 104)

\begin{abstract}
"The major impact of the Diccionario Básico Escolar is of a social and educative character because the pupils of the second circle of Primary School, Basic Secondary School and High School in Cuba can count on this work that will assist them in their linguistic, cultural, scientific, ethic and patriotic formation." (p. 110)
\end{abstract}

From the above it results that the dictionary, in the first place, is designed to assist school children of Grades 5 to 12 having lexicographically relevant information needs related to text reception, text production and their cognitive formation. However, when it comes to, for instance, ethic and patriotic formation it seems unlikely that any school child will consult a dictionary with the immediate purpose of obtaining such a formation. It rather seems to be an overall objective which little by little is achieved by mediation of continuous consultations due to more specific needs related to text reception, text production, etc. In this respect, it is important to notice that 
while ideology is always, in one way or another, transmitted through lexicographical explanations and even reflected in the selection of lemmata and examples, this inevitable and sometimes subtle transmission of ideas is seldom admitted or recognized by dictionary authors and publishing houses who prefer to maintain the false appearance of a non-existent objectivity and neutrality. Whether or not one agrees with the specific ideology, it is therefore refreshing to meet a dictionary - as was also the case with the Diccionario Escolar Ilustrado - that openly informs about the social, ethic, patriotic, and other values it intends to pass on to its users.

The more than 10500 lemmata have been selected from various sources: the corpus described above, textbooks from various grades, Cuban newspapers and magazines for young people, as well as a special corpus based upon a study of the school children's use of affixes in Grades 7 to 9. The selection represents modern Spanish language including a number of Cubanisms, Americanisms and, to a less extent, Anglicisms and Galicisms as well as hundreds of terms taken from scientific disciplines studied at the various grades.

The articles are much more complex in terms of data categories and structure than the ones in the Diccionario Escolar Ilustrado in this way reflecting the higher mental and linguistic level of the target user group. Apart from the lemma and explanation (frequently of various senses), they always contain:

- part of speech;

- example sentences;

- hyphenation, and

- inflection (of nouns, adjectives and verbs, in this last case with indication of past participle and reference to a list of 83 model verbs in the back matter of Volume II).

To this should be added the frequent inclusion of:

- underlining of certain letters in the lemma in order to warn against typical orthographic mistakes;

- gender;

- explicit grammatical data;

- diatechnical, diatopic, diaintegrative and diastratic marking;

- pronunciation (when it is a foreign word, e.g. iceberg);

- synonyms, antonyms, and cognate words;

- locutions, phraseologisms, and proverbs,

- explanation of locutions, phraseologisms, and proverbs;

- example sentences with locutions and phraseologisms;

- diminutives and augmentatives, and

- references to 19 thematic tables with a total of 584 illustrations in the back matter of Volume I.

The following three articles provide an idea of how the articles are designed:

gota sf. 1 Porción pequeña de un líquido que al caer adopta la forma de una esfera. Noté que el tiempo cambiaba cuando sentí caer de repente dos gotas de lluvia sobre mi brazo. 2 Poca cantidad de algo. Me ha servido una gota de comida. Sin. pizca. 3 Enfermedad que produce dolor en las articulaciones y a veces afecciones viscerales. Los enfermos de gota tienen un tratamiento médico intenso. // loc. adv. ni gota. Nada, ninguna cosa. No encontré ni gota de lo que me pediste. // fras. sudar la gota gorda. Esforzarse mucho para conseguir algo. Sudó la gota gorda para llegar hasta aquel lugar. go-ta; gotas (pl.); gotica (dim.) 
gracioso, a adj. 1 Se dice de lo que tiene cierto atractivo en su aspecto. Las muchachas celebran a los jóvenes graciosos. Sin. bonito, atractivo, simpático. Ant. feo. 2 Se aplica a aquello que resulta chistoso, cómico o que nos hace reír. Nos pareció gracioso el espectáculo. Sin. divertido, agradable, cómico. 3 Se atribuye a la persona que hace chistes, cuentos, etc. Jorge era el actor más gracioso de ese elenco. Sin. ocurrente. gra-cio-so, a; graciosos, as (pl.)

parecer vintr. (27) 1 Tener algo determinado aspecto físico o apariencia. El trabajo que le encomendaron parecía fácil. Su padre nos pareció muy amable. 2 vpr. Tener alguien o algo un aspecto o apariencia semejante o común a otra persona o cosa. Odilia se parece mucho a su hermana. Sin. semejarse. 3 vintr. Haber o existir razones para creer una cosa. Parece que va a salir el Sol. (Solamente se emplea en tercera persona). // loc. adv. al parecer, según parece. Como se observa o por lo que se sabe. Al parecer, a Carlos se le hizo tarde. El profesor, según parece, está enfermo y no vendrá hoy a clases.

pa-re-cer; perecido (p.p.)

As to the three functions discussed above, it seems that the Diccionario Básico Escolar complies with the requirements in this regard, at least in terms of the data categories needed to meet the school children's lexicographical needs. As to text production, the short explanation of the lemmata as well as of the locutions, phraseologisms and proverbs, written in a simple and clear language, much more "defining" than in the Diccionario Escolar Ilustrado and always followed by an example sentence, is virtually what is needed to help the children understand the words - and their various senses - included in the dictionary. As to text production, the Diccionario Básico Escolar contains a variety of data categories providing information about orthography, pronunciation, part of speech, inflection, locutions, phraseologisms, proverbs, synonyms, antonyms, cognate words, diminutives, augmentatives, and hyphenation which are all highly relevant for text production. Although some of these data categories are seldom found in school dictionaries, they are nevertheless absolutely necessary not only in order to assist the children in composing texts in correct Spanish, but also to develop and produce a rich and varied language in terms of words and expressions, and in this sense the dictionary fully accomplishes its text-productive function. And as to its cognitive function, in its various aspects, a look at the following random article providing important encyclopaedic information about electricity is sufficient to confirm that the dictionary in this respect also lives up to its promises:

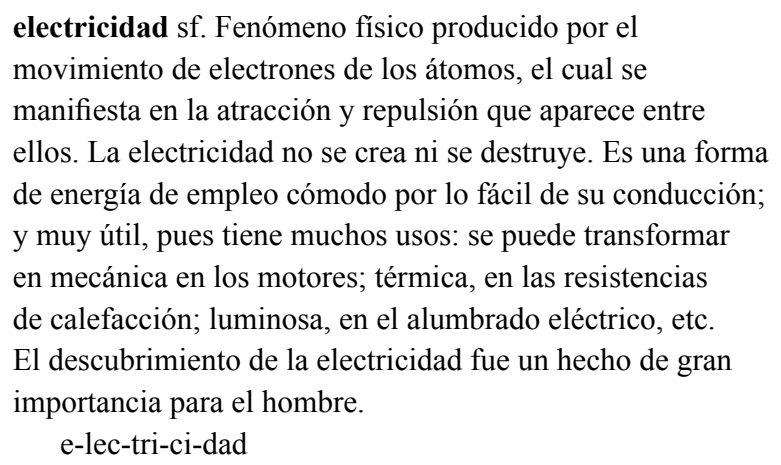

\section{Some problems and suggestions}

From the above, it becomes clear that the Diccionario Básico Escolar in many aspects is an excellent school dictionary and probably one of the best Spanish dictionaries of its kind for the user group in question, or at least part of this group. For it cannot be ignored that a major problem re- 
lated to this dictionary seems to be the many grades (and years of age) that it pretends to embrace, a comment which was also made by Forgas and Bargalló (2006: 254) who called it "a maybe too excessive ambition" because of the "big cognitive and academic difference" between the users of the upper and lower grades covered by the dictionary. This is similar to the preoccupation formulated by Gouws and Tarp (2012), although at a more abstract and theoretical level.

If one compares the Diccionario Escolar Ilustrado and the Diccionario Básico Escolar what immediately calls the attention are the big differences in terms of the quantity of data and data categories as well as the more compact article structure, a fact that may not be justified by the transition from Grade 4 to Grade 5 of Primary School. Without knowing well the curriculum of the various grades in the Cuban school system, it nevertheless seems unlikely that Cuban school children of Grades 5 and 6 may understand abbreviations like adv. l., loc. conj., loc. nom., vin$t r ., v p r$., etc., which even in their full form represent very abstract grammatical concepts. And the problem here is not only understanding, but also whether these and other abstract abbreviations which sometimes appear many times in one and the same article will "disturb data access and information retrieval" for the children at the lower levels and, consequently, reduce the usefulness of the dictionary.

By contrast, for the users in High School and even Secondary Basis School it seems that a selection of 10500 lemmata may be too little to satisfy their needs, especially in terms of text reception. If one compares the Diccionario Básico Escolar with two English school dictionaries, the Macmillan School Dictionary and the Longman South African School Dictionary, one will find that each of these two dictionaries contains about 20000 lemmata, i.e. more or less the double of the Cuban school dictionary. Especially the South African dictionary - the Macmillan School Dictionary does not specify the grades of its user group - has many similarities with the Cuban one, both in terms of covering a specific variant of English and in terms of its target user group which is described as school children from Grades 4 to 9, although it is "also relevant from Grades 10 to 12 ". Although two languages and school systems cannot be compared without certain reservations, this fact is nevertheless an indication that more lemmata - and senses - may be needed in order to cover the upper-level, and even intermediate-level, Cuban school children's lexicographical needs. If this is true, what could be suggested is to divide the Diccionario Básico Escolar into at least two different dictionaries, each of which could be much more adapted to the specific intellectual, linguistic, cultural, and encyclopedic level of the school children at the various grades.

One of the many qualities that distinguish the Diccionario Básico Escolar is the relatively big amount of explicit syntactic data, especially locutions and phraseologisms, which allow the users to compose correct and complex sentences in modern Spanish. However, even more of these data may be needed in order to guarantee this fluency in text production. For instance, many native Spanish-speaking people, both children and adults, have doubts whether it is correct or not to include "de" in common locutions like estar seguro (de) que. This locution appears implicitly in the example sentence under the lemmata seguro but in order to assist the users even more it could be recommended that this information is also offered explicitly here and in other similar cases, e.g. related to the verb dudar which, surprisingly, is not even selected as a lemma (together with other words which one would also expect to find in the dictionary).

One of the major challenges for the designers of dictionaries is to facilitate the users' quick and easy access to the relevant lexicographical data, cf. Tarp (2009a). Quick and easy access is one of the basic criteria for user-friendliness and quality. If it is too difficult and takes too long to find the needed data - and even worse, if the user gets lost en route - then the dictionary does not fulfil its purpose as an information tool. The Diccionario Básico Escolar seems to display two problems of importance in this regard, two problems with more or less the same solution. The first problem is the one also mentioned in connection with the Diccionario Escolar Ilustrado, i.e. the compact article structure, especially when there are two or more senses treated. The article cabeza, for instance, treats three senses of cabeza, but the second is hidden 29 lines below the lemma, a complication that probably will prevent some of the users, especially from the lower grades, from 
reaching this sense when they do a quick consultation, e.g. in relation to text reception. To solve this problem, therefore, it would be recommended to introduce a search-field structure where new senses and important data categories appear on a new line just as the data about hyphenation and inflection do in the present structure. If one takes the article gota shown above, an alternative structure based upon the principle of search fields - and introducing some lexicographical symbols and other small modifications - could be as follows:

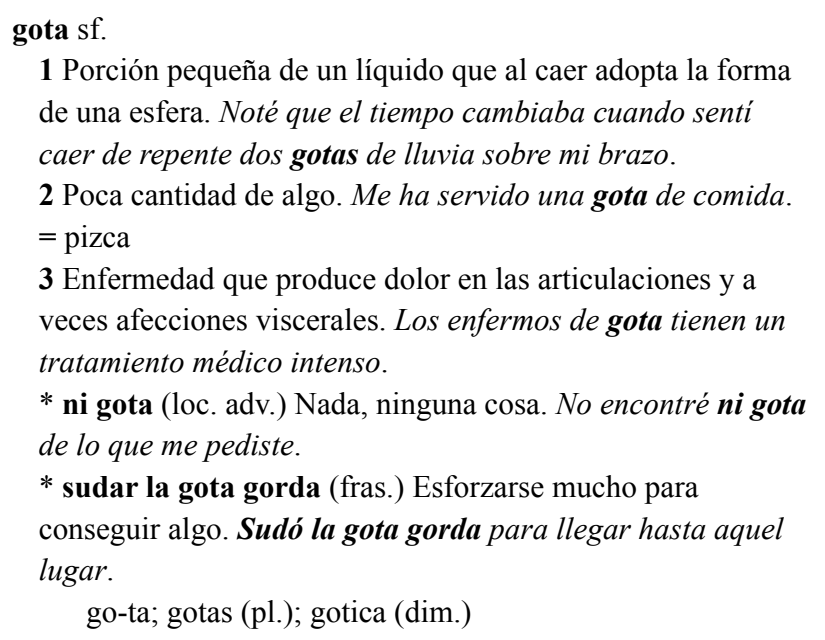

The only inconvenience in using a search-field structure like the one shown above is that it requires a little more space - and in the end, if it cannot be solved by a different layout, more paper and money - but it is worth considering if this is not compensated by the much higher user-friendliness in terms of quick and easy access to the relevant lexicographical data.

The second problem in terms of access is related to the treatment of polysemy and homonymy. In her Introduction to the third edition, Eloína Miyares Bermúdez explains:

"Homonymy is also present in the Diccionario Básico Escolar, as in cerca (s.)/cerca (adv.), cantar

(s.)/cantar (v.), etc., thus contributing to a better knowledge and proper use of the language."

In linguistic theory, a distinction is made between three types of homonymy: etymological homonymy based upon a diachronic analysis of the words, semantic homonymy based upon a synchronic analysis of the words, and grammatical homonymy based upon an analysis of the syntactic properties of the words, cf. Tarp (2009b: 293). It is nowhere stated which of the three types is used in the Diccionario Básico Escolar but it seems to be the second, i.e. semantic homonymy. In A Dictionary of Linguistics and Phonetics, Crystal (1991: 236) discusses the problems related to the differentiation between polysemy and homonymy:

"The theoretical problem for the linguist is how to distinguish polysemy $[\ldots]$ from homonymy $[\ldots]$. Several criteria have been suggested, such as etymology [...], and the closeness of the relationship between the meanings in question [...]. But all such criteria involve analytic problems, and the distinction between polysemy and homonymy thus remains a source of theoretical discussion in linguistics."

Under the lemma polysemy in his Concise Oxford Dictionary of Linguistics, Matthews (2005) adds that "there are inevitably cases that are indeterminate". The result of these "analytic problems" and "indeterminate cases" is, according to Malakhovsky (1987: 36), that

\footnotetext{
"every lexicographer solves the problem in his own way, either on the basis of his subjective ideas about the nature of form-to-meaning relationships between homonymous words or by following an existing lexicographical tradition. Hence the amazing variety of methods used in current dictionaries to present homonyms."
}

There may be better or worse linguistic theories in terms of a more precise distinction between homonymy and polysemy, and there may be a majority of cases where there is little doubt as to how to classify a specific word based upon etymological or semantic criteria. However, the prob- 
lem for the users - and especially the school children - is that they, in any case, cannot be expected to know these theories and criteria and that, hence, they will not understand why one word is treated in a single article and another word in two articles, and this may at the end of the day lead to doubts, access problems and waste of time. In order to solve this problem for the benefit of the users, it could be recommended to apply the criterion of grammatical homonymy which is very easy to establish as two words may be considered grammatically homonymous when they have the same form, but belong to different parts of speech, different genders or different flexion paradigms. The very practical and user-friendly lexicographical consequence of this criterion is that a word, when it is grammatically homonymous, is treated in two or more articles, and when it is not, in one and the same article just like any polysemous word. Let us take two words from the Diccionario Básico Escolar, centenario and llama, this first also discussed by Miyares and Ruiz (2006: 105) and treated as a polysem, and the second treated as a homonym:

centenario, a adj. 1 Que tiene cien años o más. Mi abuelo el

mes pasado cumplió ciento dos años, es centenario. $2 \mathrm{sm}$.

Tiempo de cien años. En 1968 se cumplió el centenario de la

guerra de los Diez Años. 3 Suceso que se conmemora cada

cien años. En el año 2003 celebraremos el segundo

centenario del nacimiento del poeta José María Heredia.

cen-te-na-rio, a; centenarios, as (pl.)

llama sf. Mamífero rumiante doméstico de abundante pelo que vive en América del Sur. Tiene la cabeza mediana, las orejas puntiagudas y los ojos grandes. Su cuello es largo y erguido, las patas son delgadas y la cola corta. Se utiliza como bestia de carga y se aprovecha su leche, su carne, cuero y pelo. Los indios peruanos transportaban minerales en llamas.

lla-ma; llamas (pl.)

llama sf. 1 Masa de gas muy caliente y luminosa que se desprende de los cuerpos que arden. La llama del fogón está baja. Sin. fuego, candela, lumbre. 2 fig. Pasión, ardor. Una

llama de amor se había prendido en su pecho adolescente. lla-ma; llamas (pl.); llamita (dim.)

If instead the criterion of grammatical homonymy is applied together with a proper search-field structure, the cards will be shuffled in a new way resulting in the following three articles:

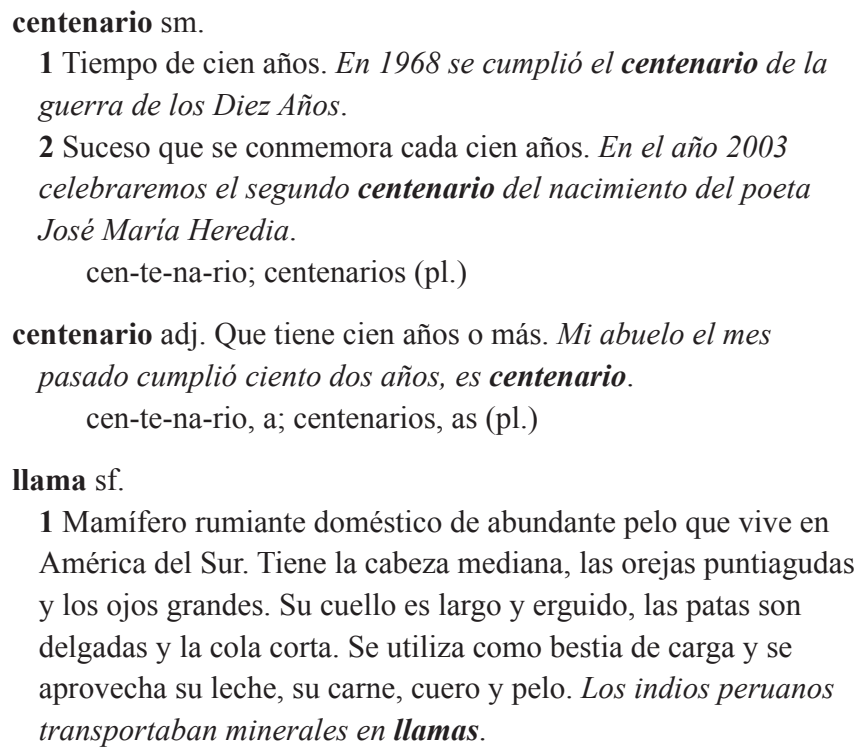


2 Masa de gas muy caliente y luminosa que se desprende de los

cuerpos que arden. La llama del fogón está baja.

= fuego, candela, lumbre

3 fig. Pasión, ardor. Una llama de amor se había prendido en su

pecho adolescente.

lla-ma; llamas (pl.); llamita (dim.)

The advantage of this structure is first of all that it is very easy to apply; second, that the users, once they understand the concept of part of speech, will know that all data addressed to a specific word belonging to a single part of speech can be found in one and the same article; and third, that the rather confusing mixture of inflection paradigms, as in the article centenario in the original version, can be avoided. By contrast, it can be claimed that with this structure the school children will not learn to distinguish between polysemy and homonymy and in this regard acquire learned knowledge of the Spanish language; this is, of course, true but the question is whether this is an important objective of the dictionary that ranks over its user-friendliness. Besides, by reading the various senses, e.g. of llama, the users can easily learn whether these senses are semantically connected or separated.

\section{The Internet version of the Diccionario Básico Escolar}

This space does not allow a profound analysis of the Internet version of the Diccionario Básico Escolar. It may just briefly be stated that it, first and foremost, is an electronic version of the dictionary in the sense that, with a few exceptions, it contains the same lexicographical data organized in the same articles as the printed edition. The biggest difference to the former is the much quicker and easier access, inclusive by means of spelling mistakes, and the linking between the articles, as well as the very important fact that it can soon be accessed from all Cuban classrooms which today are equipped with computers, screens and access to the national Intranet.

Another relevant improvement is that the articles display a much more user-friendly architecture that follows the principle of search fields described above. Even so, the articles popping up on the screen are static; it is, for instance, not possible to search for and directly access locutions, phraseologisms and proverbs. The phraseologism hacer de tripas corazón and the proverb la cabra tira al monte, for example, can only be accessed through the articles tripa and cabra, respectively, in spite of the fact that a user who has a reception problem regarding these expressions does not need the other data addressed to tripa and cabra which are redundant and may even be disturbing in such a case. Neither does the present Internet version allow a differentiated search process adapted to the various functions (i.e. the needs related to text reception, production and cognitive formation) or grades of the user group.

In fact, some of the problems discussed above in terms of abundance of data and data categories for the lower grades and too little data for the upper grades could be solved relatively easy in an electronic version using the available technology. In this respect, the Internet version of the Diccionario Básico Escolar belongs to that majority of electronic dictionaries which Tarp (2011b: 59-61) categorizes as "faster horses" in contradistinction to the more advanced lexicographical "Model T Fords" which are characterized by "dynamic articles with dynamic data" adapted to the target user group's needs in the situations that these dictionaries pretend to cover. "Faster horses" represent a step forward for lexicography but not as much as the "Model T Fords" which are little by little appearing as members of the big family of dictionaries.

\section{Conclusions}

The Santiago-based Centro de Lingüistica Aplicada has produced two school dictionaries, the Diccionario Escolar Ilustrado and the Diccionario Básico Escolar, which together cover the 12 grades from Primary School over Secondary Basic School to High School. In various ways they are innovative in terms of the solid preparatory work, the design and content of the articles, the 
inexpensive production methods, and the work that has been carried out with a view to effectively reaching the target user group with an output of until now more than 100000 printed copies as well as their accessibility on $\mathrm{CD}$, the Internet and the Cuban national Intranet (soon).

No dictionary is born fully armed as Athena from Zeus' forehead, and the two Cuban school dictionaries are no exception to this rule. Compared to the present standard of Spanish and international school dictionaries, they may both be considered excellent dictionaries although they can certainly be further improved, especially the Diccionario Básico Escolar which seems to suffer from some internal contradictions due to the excessive number of grades it seeks to cover. In spite of this, this dictionary may even be recommended to foreign learners of Spanish, first of all because of the clear and simple explanations and the amount of highly relevant syntactic data which are seldom found in Spanish dictionaries for second-language learners, and secondly because it can easily be accessed through the Internet. Hopefully, 2012 will see new improvements when new printed and electronic editions of the two dictionaries will be published for the benefit of thousands of Cuban school children and other interested people.

\section{Literature}

\subsection{Dictionaries}

Bullon, Stephen (Ed.) 2007: Longman South African School Dictionary. Essex: Pearson Education Limited.

Crystal, David 1991: A Dictionary of Linguistics and Phonetics. Cambridge: Basil Blackwell.

Matthews, Peter H. 2005: Concise Oxford Dictionary of Linguistics. Oxford: Oxford University Press.

Miyares Bermúdez, Eloína (Ed.) 1998: Diccionario Escolar Ilustrado. Santiago de Cuba: Editorial Oriente/Madrid: Ediciones Libertarias.

Miyares Bermúdez, Eloína (Ed.) 2003: Diccionario Básico Escolar. Primera edición. Santiago de Cuba: Centro de Lingüística Aplicada.

Miyares Bermúdez, Eloína (Ed.) 2008: Diccionario Básico Escolar. Segunda edición. Santiago de Cuba: Centro de Lingüística Aplicada.

Miyares Bermúdez, Eloína (Ed.) 2009: Diccionario Básico Escolar. Tercera edición. Santiago de Cuba: Editorial Oriente.

Miyares Bermúdez, Eloína (Ed.) 2009: Diccionario Básico Escolar. Edición electrónica, versión 3.0. Santiago de Cuba: Centro de Lingüística Aplicada/Donostia: IXA Taldea, Universidad del País Vasco [online]. http://ixa2.si.ehu. es/dbe/index.html.

Rundell, Michael (Ed.) 2004: Macmillan School Dictionary. Oxford: Macmillan 2004.

\subsection{Other literature}

Alegría, Iñaki/Arregi, Xabier/Artola, Xabier/Astiz, Mikel/Miyares, Leonel Ruiz 2006: Different issues in the design and development of the electronic Cuban Basic School Dictionary. In Bermúdez, Eloína Miyares/Miyares, Leonel Ruiz (Eds.), Linguistics in the Twenty First Century. Cambridge: Cambridge Scholars Publishing, 273-288.

Avendaño, Bárbara 2011: Saboreando el rico español. Bohemia, 17 de noviembre de 2011 [online]. www.bohemia. cu/2011/11/17/ciencia/linguistica-aplicada.html.

Corpas Pastor, Gloria 2005: [Review of] Eloína Miyares Bermúdez (ed.)., Diccionario Básico Escolar. Santiago de Cuba: Centro de Lingüística Aplicada. 2003. In International Journal of Lexicography 18 (2), 267-272.

Forgas, Esther/Bargalló, María 2006: Los diccionarios del Centro de Lingüística Aplicada de Santiago de Cuba. In Revista de Lexicografia XII, 249-266.

Gouws, Rufus/Tarp, Sven 2010: Skoolwoordeboeke vir huistaalleerders van Afrikaans. In Lexikos 20, 466-494.

Gouws, Rufus/Tarp, Sven 2012: School dictionaries for first-language learners. In Lexikos 22 (to appear).

Hausmann, Franz Josef 1989: Die gesellschaftlichen Aufgaben der Lexikographie in Geschichte und Gegenwart. In Franz Josef Hausmann/Reichmann, Oskar/Wiegand Herbert Ernst/Zgusta, Ladislav (Eds.), Wörterbücher, Dictionaries, Dictionnaires. An International Encyclopedia of Lexicography I. Berlin/New York: Walter de Gruyter, 1-19.

Hausmann, Franz Josef 1990: Das Kinderwörterbuch. In Hausmann, Franz Josef/Reichmann, Oskar/Wiegand, Herbert Ernst/Zgusta, Ladislav (Eds.), Wörterbücher, Dictionaries, Dictionnaires. An International Encyclopedia of Lexicography II. Berlin/New York: Walter de Gruyter, 1365-1368. 
González, Heredi/Amed, Roberto/Miyares, Leonel Ruiz/Bermúdez, Eloína Miyares 2011: La versión electrónica del Diccionario Escolar Ilustrado. In Miyares, Leonel Ruiz/Silva, María Rosa Álvarez (Eds.), Comunicación Social en el Siglo XXI, Vol. II. Santiago de Cuba: Centro de Lingüística Aplicada, 1077-1080.

Hernández, Humberto Hernández 1989: Los diccionarios de orientación escolar. Contribución al estudio de la lexicografía monolingüe española. Tübingen: Max Niemeyer Verlag.

Hernández, Humberto Hernández 2003: La lexicografía escolar del español: desde sus orígenes hasta su consolidación. In Revista Internacional de Lingüistica Iberoamericana I, 7-25.

Malakhovski, Lev V. 1987: Homonyms in English Dictionaries. In Robert William Burchfield (Ed.), Studies in Lexicography. Oxford: Clarendon Press, 36-51.

Miyares Bermúdez, Eloína/Ruiz Miyares, Leonel 2006: Dos ejemplos de la lexicografía pedagógica cubana: el Diccionario Escolar Ilustrado y el Diccionario Básico Escolar. In Campus Soutu, Mar/Córdoba Rodríguez, Felix/ Pérez Pascual, José Ignacio (Eds.), América y el diccionario. A Coruña: Universidade da Coruña, 197-211.

Miyares Bermúdez, Eloína (Ed.)/Suárez, Nancy C. Álamo/Márqués, Celia Pérez/Heredia, Katia González/Miyares , Leonel Ruiz 2006: Léxico activo-funcional del escolar cubano. Santiago de Cuba: Centro de Lingüística Aplicada.

Nomdedeu Rull, Antoni 2012: [Review of] Miyares Bermúdez, Eloína (dir.) (2009): Diccionario básico escolar. Santiago de Cuba, Centro de Lingüística Aplicada. In Revista de Lexicografía (to appear)

Tarp, Sven 2008: Lexicography in the Borderland between Knowledge and Non-knowledge. General Lexicographical Theory with Particular Focus on Learner's Lexicography. Tübingen: Max Niemeyer.

Tarp, Sven 2009a: Reflections on data access in lexicographic works. In Nielsen, Sandro/Tarp, Sven (Eds.), Lexicography in the 21st Century. Amsterdam, Philadelphia: John Benjamins Publishing Company, 43-62.

Tarp, Sven 2009b: Homonymy and polysemy in a lexicographic perspective. In Henning Bergenholtz and Thomas Herbst (Eds.), Classifications in Lingistics and Lexicography. Special Issue of Zeitschrift für Anglistik und Amerikanistik 57 (3), 289-306.

Tarp, Sven 2011a: Pedagogical Lexicography: Towards a New and Strict Typology Corresponding to the Present Stateof-the-Art. In Lexikos 21, 217-231.

Tarp, Sven 2011b: Lexicographical and Other e-Tools for Consultation Purposes: Towards the Individualization of Needs Satisfaction. In Fuertes-Olivera, Pedro A./Bergenholtz, Henning (Eds.), e-Lexicography: The Internet, Digital Initiatives and Lexicography. London, New York: Continuum, 54-70.

Welker, Herbert Andreas 2008: Panorama geral da lexicografia pedagógica. Brasilia: Thesaurus Editora.

Wiegand, Herbert Ernst 1977: Nachdenken über Wörterbücher. Aktuelle Probleme. In Drosdowski, Günther/Henne, Helmut/Wiegand, Herbert E., Nachdenken über Wörterbücher. Mannheim, Vienna, Zürich: Bibliographisches Institut, 51-102.

Wiegand, Herbert Ernst 2000: Über Suchbereiche, Suchzonen und ihre textuellen Strukturen in Printwörterbüchern. In Herbert E. Wiegand (Ed.), Wörterbücher in der Diskussion IV. Vorträge aus dem Heidelberger Lexikographischen Kolloquium. Tübingen: Niemeyer, 233-301. 